Taxation in Colonial America 
This page intentionally left blank 


\title{
登誉
}

\section{Taxation in Colonial America}

\author{
A LVIN RABUSHKA
}

PRINCETON UNIVERSITY PRES S

PRINCETON AND OXFORD 
Copyright (C) 2008 by Princeton University Press

Published by Princeton University Press, 4I William Street, Princeton, New Jersey 08540

In the United Kingdom: Princeton University Press, 3 Market Place, Woodstock,

Oxfordshire $\mathrm{OX}_{20} \mathrm{ISY}$

All Rights Reserved

Library of Congress Cataloging-in-Publication Data

Rabushka, Alvin.

Taxation in colonial America / Alvin Rabushka.

p. cm.

Includes bibliographical references and index.

ISBN 978-o-69I-I3345-4 (hardcover : alk. paper) I. Taxation-United States-History-I7th century. 2. Taxation-United States-History-I8th century. 3. United States-

History-Colonial period, ca. I600-I775. I. Title.

$\mathrm{HJ}_{23} 68 . \mathrm{R}_{33} 2008$

336.200973'09032-dc22

2007026175

British Library Cataloging-in-Publication Data is available

This book has been composed in Adobe Caslon

Printed on acid-free paper. $\infty$

press.princeton.edu

Printed in the United States of America

$\begin{array}{llllllllll}\text { I } & 3 & 5 & 7 & 9 & \text { IO } & 8 & 6 & 4 & 2\end{array}$ 


\section{登誉}

For Alexander, Nicholas, Hunter, and Julia

The Promise of America 
This page intentionally left blank 